\title{
Palm Sap Sources, Characteristics, and Utilization in Indonesia
}

\author{
Teguh Kurniawan ${ }^{1, *}$, Jayanudin ${ }^{1, *}$, Indar Kustiningsih", Mochamad Adha Firdaus ${ }^{2}$ \\ ${ }^{1}$ Chemical Engineering Department, Universitas Sultan Ageng Tirtayasa, Cilegon, Indonesia \\ ${ }^{2}$ Chemical Engineering Department, King Fahd University of Petroleum and Minerals, Dhahran, Saudi Arabia \\ *Corresponding author: teguh@untirta.ac.id; jayanudin@untirta.ac.id
}

Received August 15, 2018; Revised September 19, 2018; Accepted September 28, 2018

\begin{abstract}
Sap from various species palm trees in which known as neera generally produced by traditional technology in Indonesia. There are 5 well known palm species that produce Neera in Indonesia such as arenga palm, coconut tree, doub palm, nipa palm and palm oil. Neera can be utilized as raw material for various derivatives such as palm sugar, sweet palm toddy, and alcoholic toddy. Tapping of neera is a crucial step because neera prone to immediately degrade and causing poor quality of palm sugar. Traditional sugar processing has some drawbacks for example: low energy efficiency processing and off-specification products. On the other side, sugar palm neera has important antioxidant component which benefits for human that unavailable in normal white sugar from sugarcane. In this current review, characterization of neera from various palms in Indonesia and available technology on sugar palm processing such as spray dryer and membrane ultrafiltration will be discussed.
\end{abstract}

Keywords: neera, palm sugar, antioxidant, spray dryer, membrane

Cite This Article: Teguh Kurniawan, Jayanudin, Indar Kustiningsih, and Mochamad Adha Firdaus, "Palm Sap Sources, Characteristics, and Utilization in Indonesia." Journal of Food and Nutrition Research, vol. 6, no. 9 (2018): 590-596. doi: 10.12691/jfnr-6-9-8.

\section{Introduction}

Sugar consumption in Indonesia approximately reaches 5.7 million metric in 2016/2017 which mainly supplied from sugarcane [1]. White sugar for non-industry consumption is produced from local sugarcane plantation. To protect local sugarcane from imported sugar, raw sugar for industrial purpose is imported and refined further in local factory. Typical Indonesia's sugarcane contains at least 9\% sucrose which is lower than sucrose content of sugarcane crop in Brazil, i.e., 14\% [2]. Sugarcane is a seasonal plant and could be harvested once a year in summer season during April to October in which reaches maximum sucrose content and easier to transports from field to the factory.

Indonesia as a tropical country has many species palm trees like coconut, arenga, doub palm, nipa and palm oil. Most of the palm trees has multipurpose function that are important for local people [3]. They gain benefits from its root to the top of the tree. Sugar also could be made from palm sap named 'neera'. Yet, sugarcane production still dominating sugar production and consumption in Indonesia. From the ecological perspective, palm trees are important because they are able to grow on marginal and on also landslide area.

In this writing, a review of various palm sugar in Indonesia will be covered including: sap tapping technique, traditional palm sugar production, and promising advanced technology to improve palm sugar quality.

\section{Sugar Crops in Indonesia}

According to Food and Agriculture Organization (FAO) there are two main sugar crops in the world: (1) sugarcane and (2) sugar beet. In Indonesia, sugar is produced primarily from sugarcane. In fact, Java, one of big island in Archipelago of Indonesia, is the second largest producer-exporter of cane sugar after Cuba in the early twentieth century under occupation of the Netherland [4]. Beside Sugarcane, Indonesia has traditionally produced sugar palm and other neera derivatives products from various palm sugar tress as presented in Table 1.

Table 1. Sugar palm in Indonesia

\begin{tabular}{|c|l|l|c|c|}
\hline No & Sugar palm species & Products of palm sap & Area of plantation (ha) & Ref \\
\hline 1 & Arenga palm (Arenga pinnata) & Jaggery, granulated palm sugar, sweet toddy, palm toddy & 9925 & {$[5,6]$} \\
\hline 2 & Coconut tree (Cocos nucifera) & Jaggery, granulated palm sugar & $1,242,319$ & {$[6,7]$} \\
\hline 3 & Doub palm (Borassus flabellifer) & Jaggery, granulated palm sugar, sweet toddy, palm toddy & 1992 & {$[6,8]$} \\
\hline 4 & Nipa palm (Nypa fruticans) & Jaggery, granulated palm sugar, sweet toddy & 700,000 & {$[9,10]$} \\
\hline 5 & Palm oil (Elaeis guineensis) & Jaggery & $3,133,711$ & {$[6,11]$} \\
\hline
\end{tabular}




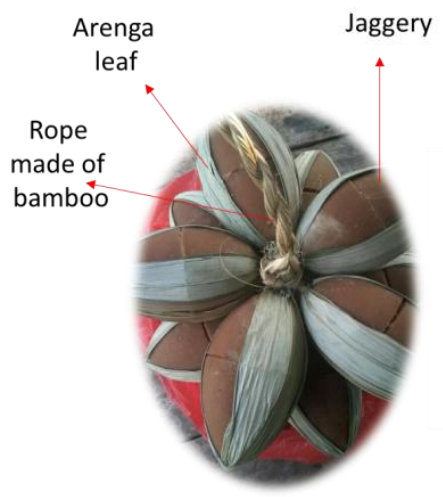

(a)

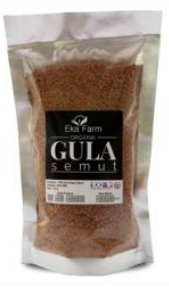

(b)

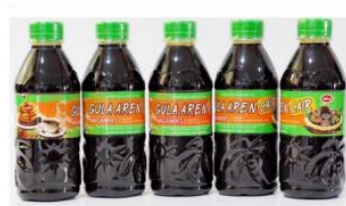

(c)

Figure 1. (a) Jaggery, a traditional product of palm sugar, is produced by open pan evaporation technique (b) granulated palm sugar (c) syrup

Jaggery is a traditional sugar brown in color made by open evaporation without centrifugation of neera derive from arenga palm, coconut tree, doub palm and nipa palm. Recently, Palm oil is also exploited for its sap from the old trunk palm oil. Some local farmer use arenga leaf to wrap the jaggery and tie several pieces of jaggery with bamboo rope (Figure 1a). Jaggery is the main product of neera. Another product of palm sugar involving granulated sugar and syrup depicted in Figure $1 \mathrm{~b}$ and 1c, respectively. The granulated sugar and syrup were recently produced by local farmer in order to diversify the sugar palm products.

The palm sugar is not only producing sugar but also other products such as sweet palm toddy (Figure 2a and 2b) and palm toddy (Figure 2c). Sweet toddy is a fresh neera extract whilst Palm toddy is a fermented Neera that usually contains alcohol. Neera from Arenga pinnata called as lahang in West Java and it is quite popular in the past (Figure 2a). Nowadays, lahang is rarely found in big city because of limited number of Arenga tree in urban area. The fresh sap from Borassus flabellifer called as legen in East Java (Figure 2b). Fresh neera gives a pleasant flavor which comes from chemical compound such as ethyl lactate, 3-hyroxy-2-pentanone, and ethylhexanoate [12].

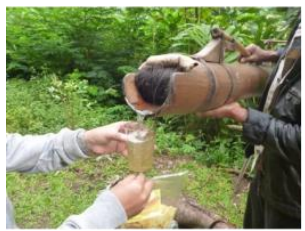

(a)

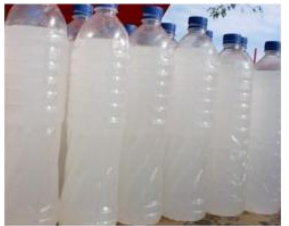

(b)

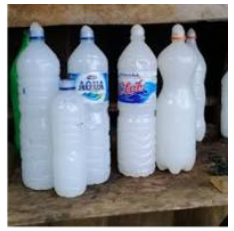

(c)
Figure 2. Beverages made of palm sap (a) sweet toddy of Borassus flabellifer (b) sweet toddy of Arenga pinnata (c) Toddy of Arenga pinnata

Palm toddy are mostly found in non-muslim population area such as in North Sumatera and North Sulawesi. Tuak is a local name for palm toddy in North Sumatera whereas in North Sulawesi, people called it as saguer. The ethanol concentration of traditional palm toddy is within the range of $5-10 \% \mathrm{v} / \mathrm{v}$ [13]. The palm toddy gives a unique flavor that come from 3-isobutyl-2-methoxypyrazine (earthy), acetoin (buttery), ethylhexanoate and 2-acetyl-1-pyrroline [12].

Sap of palm trees contains different total sugar concentration depend on the species. Each palm tree has its own characteristic of sap production way as presented in Table 2.

\subsection{Arenga Pinnata}

Arenga pinnata has many local name from east to west of Indonesian Archipelago such as sageru (Maluku), seho (Manado), nau (Timur), maoke (Flores), kalotu (Sumba), Nao (Bima), Pola (Sumbawa), hano (Bali), aren (Jawa, Madura), kawung (Sunda), hanau (Kerinci), poula (Mentawai), peto (Nias), bargot (Mandailing), ijuk (Gayo), pola atau paula (Karo), bagot atau agaton (Toba), dan bak juk (Aceh) [21]. The various local name of Arenga pinnata in Indonesia indicates that this tree is a multipurpose plant. The root extract usually made as a tea to cure bladder stones; insect repellent and erosion control. The core trunk is rich with starch. Black fibers of arenga is well-known for its strength rope. The leaves are used for house roof whereas the unversed leaves utilize as cigarette additive. Meanwhile, the fruit served as a dessert [3].

Arenga's sap containing sucrose between 10 and $20 \%$ that is ideal to produce sugar. The sap also can be directly feed for pig which practiced traditionally in two Indonesian small islands, Roti and Savu for centuries [22]. Neera is easy to be spoiled and deteriorated by contamination of Saccharomyces cerevisiae. The $\mathrm{pH}$ of neera will be below of seven because of acid produced by microorganism activity. Preservation of neera could be performed traditionally by adding lime and stem bark of Jackfruit tree (Artocarpus heterophyllus) [23]. Before tapping the palm sap, farmers usually beat the stalk by wooden mallet to improve the yield of palm sap [24].

Table 2. Palm sap characteristics of various palm trees in Indonesia

\begin{tabular}{|c|c|c|c|c|c|c|}
\hline No & Palm species & $\begin{array}{c}\text { Age of tree ready for } \\
\text { tapping [years] }\end{array}$ & $\begin{array}{c}\text { Sap production } \\
{[\text { liter/(day. palm) }]}\end{array}$ & $\begin{array}{c}\text { Sap production life } \\
\text { span [years] }\end{array}$ & $\begin{array}{l}\text { Sugar content in } \\
\text { palm sap }(\%)\end{array}$ & Ref. \\
\hline 1 & Arenga pinnata & $7-10$ & $10-15$ & Several years & $10-20$ & {$[15]$} \\
\hline 2 & Cocos nucifera & 7 & $1.7-4.3$ & 20 years & $15-18$ & {$[16,17]$} \\
\hline 3 & Borassus flabellifer & $15-30$ & 6 & 30 to 100 & $9-17$ & {$[18]$} \\
\hline 4 & Nypa fruticans & 4 & $0.2-2$ & 50 & 15 & [19] \\
\hline 5 & Elaeis guineensis & 6 & - & 10 to 15 & $9-11$ & {$[20]$} \\
\hline
\end{tabular}




\subsection{Cocos Nucifera}

Coconut tree is also traditionally exploited for its neera which contains mainly sucrose. One example of coconut sap from Malang, East Java, contained $70.85 \%$ sucrose, $3.00 \%$ glucose and $2.92 \%$ fructose [25]. Coconut sap is the raw materials for various products i.e. palm syrup, palm jaggery, palm honey, palm candy, chocolate toffees and confectionery items, molasses, coconut vinegar, neera soft drink, neera cookies, neera chocolate, and neera sweet [26]. The coconut palm sugar product should have a proper packaging. Sutthachaidee suggested that the packaging of coconut sugar coffee spoon should meet 5 criteria [7]. First, the designs should accommodate the sense of local natural resources and cultural wisdom, second the design should be simple for production; third, the designs should have low prices; fourth, the designs should be attractive, pleasing and unique, and lastly, the designs should be moveable for travelers, appropriate as a souvenir, and the packages should be designed for ease of distribution and transportation.

The technique of tapping palm sap is similar for arenga, coconut, doub palm and nipa palm except for the palm oil which extracted sap from its trunk (Figure 3 ). The coconut sap obtained by cutting the inflorescence stalk of a coconut tree which is usually done in the afternoon; cleaning and beating the stalk for producing high quality coconut sap; attaching a bamboo tube to store the sap and afterward, collecting it for the next morning.

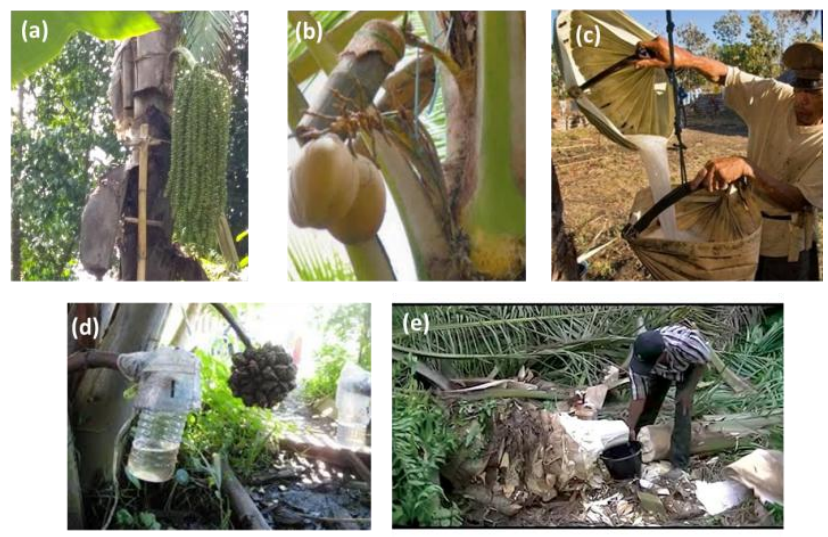

Figure 3. Tapping palm sap of (a) Arenga pinnata (b). Cocos nucifera (c) Borassus flabellifer (d) Nypa fruticans and (e) Elaeis guineensis

\subsection{Borassus Flabellifer}

Palm sap quality of Borassus flabellifer are vary depend on genetic and metabolite characteristics of the tree, environment factors, the collecting time, microbial load, personal hygiene and sanitary equipment. The microorganisms possibly become significant factor on quality of palm sap because they use sugar as substrate to produce organic acids and ethanol. These organic acids cause the inversion reaction whilst ethanol has unpleasant flavor of palm sap [27].

Reshma et. al. [8] has successfully extract 2,3,4-trihydroxy-5-methylacetophenone, nicotinamide, and uracil of palmyra palm syrup by using chloroform and butanol. The 2,3,4-trihydroxy-5-methylacetophenone is exhibited DPPH radical scavenging activity that used as antibacterial against Escherichia coli, Staphylococcus aureus, Mycobacterium smegmatis, and Staphylococcus simulans.

\subsection{Nypa Fructicans}

Nipah is one of Arecaceae species which growths in swamp area and estuary. The fruit have bunch similar like fruits of palm oil with hard skin and brown color. Nipa is spread out in Indonesian along with mangrove. Nipa also has many local name such nipah (Java), buyuk (Bali), bhunyok (Madura), bobo (Menado, Ternate, Tidore), boboro (Halmahera), and palean (Moluccas).

The nipa sap production is within the range of 0.4 to 1.0 $\mathrm{L} /$ (day.palm) with sugar contents vary from $15 \%$ to $21 \%$ (w/w). Timing for tapping is very important. Palms typically are tapped for 38 to 63 days per tapping season which equals to 2 or 3 cycles and makes tapping could only be done from 80 to 180 days per year [9]. Päivöke reported that nipa could be tapped until 100 days per year for a life span of more than 50 years, yielding a maximum of $1.3 \mathrm{~L} /$ day per palm of sap [28]. The result confirmed by Tamunaidu investigation that the 100 years nipa yield 0.3 to $1.4 \mathrm{~L} /$ day [9].

In South Kalimantan, traditionally palm stalk was shaked for 15-20 days before sap tapping. The palm stalk was cut with angles $30-45^{\circ}$ facing down to avoid exposure direct sunlight. Each container sap was wrapped by lime with concentration of $1.5 \mathrm{~g} /$ liter sap. The nipa sap tapping was carried out in the morning and the afternoon [29]. The nipa sap then crystallized into granulated brown sugar.

\subsection{Elaeis Guineensis}

Sugar extracted from palm oil of Nigeria contains 9.6 to $10 \%$ sucrose $[11,22]$. The tapping of palm oil sap in Nigeria is quite similar with any palm sugar tree that is by cutting the inflorescence flower [20]. Typically, oil is the only product of palm oil. Zahari reported that pressed oil palm frond (OPF) juice contain sugar of glucose $(71 \%)$, sucrose $(27 \%)$, and fructose (2\%). By using a simple sugarcane press, $50 \%(\mathrm{wt} / \mathrm{wt})$ of OPF juice was obtained from fresh OPF [30].

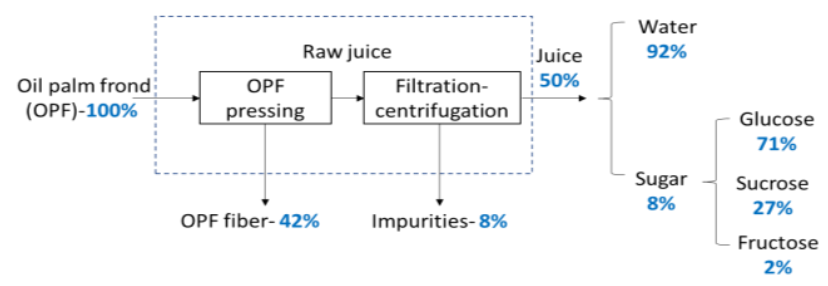

Figure 4. Extracting sugar from oil palm frond and fermenting into alcohols

The sucrose content of OPF juice is quite low, while glucose content is very high. Instead of making sugar from OPF juice, it is much easier to convert sucrose and glucose into ethanol via fermentation process [31]. Extracting sugar from oil palm frond and fermenting into alcohols as presented in Figure 4 is ideal solution to utilize the OPF juice. Development of sap compression system is critical to obtain high yield of OPF juice [32]. 
Recently, palm sap also had produced from palm oil. However, the source of sap is not from male inflorescence but from the felled palm oil trunk [33]. Local farmer tapping the sap from its fell trunk in replanting period. Usually after 20 years, palm oil needs to replant by cutting down the old palm oil tree and replant with the new one which taking time within the range of 30-40 days. The produced sap then processed to produce jaggery. This new method potentially applied to increase sugar production from palm oil plantation which is the largest in the world.

\section{Traditional Sugar Production}

The typical processing of sugarcane to produce white sugar utilized by modern methods like sulphitation and carbonation followed by evaporation, crystallization and centrifugation. However, these process removes almost all antioxidant containing in the juice along with other impurities. On the other hand, simple handling of palm sugar processing done by heating in a large pan for several hours until crystallized sugar occur could preserve the antioxidant components in traditionally produced sugar. Generally, the process of sugar making for all palm sap or neera is similar [7,24]. The collected neera then filtered by sheet cloth and pouring into large pan. Afterward, neera cooked for 3-4 hours to high concentration of brown sugar that indicated by very viscous appearance. Afterward, the hot sticky brown sugar pouring down into mold made of bamboo, wood, or coconut shell. The sugar will be cooling down and hardened after 1 hour and ready for packaging.

Traditional sugar processing produce sugar with brown color because of browning and Maillard reaction (Figure $6)$. High temperature and long heat treatment on the open pan evaporator favored the browning and Maillard reaction [34,35]. Furthermore, the phenolic compounds and antioxidant properties of date syrup become decreased after high temperature treatment [36]. The disadvantage of using an open pan evaporator lead to a higher sucrose inversion and hydroxymethylfurfural formation with less glucose and fructose. On the contrary, a vacuum evaporator runs under lower temperature than open evaporator could reduce the sucrose inversion [18].

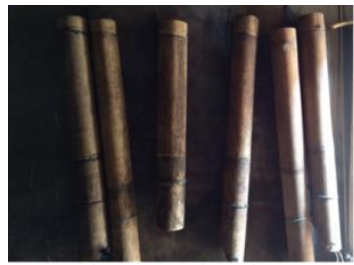

Palm sap in bamboo
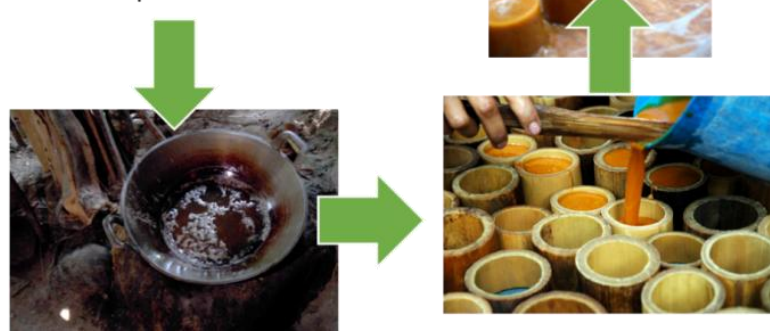

Figure 5. Traditional palm sugar processing

\section{Spray Dryer for Sugar Production}

The method of palm sugar processing can affect its characteristics and quality. Conventional method that has been used to produce palm sugar causes palm sugar to be dark brown and taste slightly bitter. The darkening phenomenon is occurred because of high temperatures operation which leads to caramelization. Another negative effect is the loss of active components due to palm sap degradation. Selection of the right technology is required to improve the quality of palm sugar. One of that has been promising method is spray drying.

Spray drying is a process to convert liquid into solid granules (Figure 7a) that has the advantage of maintaining good product quality in just a little time. Derivatives palm sugar from spray drying also has low water content and easier to be stored [37]. Spray drying widely used in the food industry to make food powder because of its effectiveness in optimal conditions. The operating conditions that mainly affect the process are the drying air temperature, feed rate that highly depend on product characterization, such as particle size, color, bulk density, moisture content, and nutrient content [38]. Temperature become the most important parameter of spray drying in which causes a higher level of evaporation of moisture, higher porosity and lower bulk density of dried powder [37].

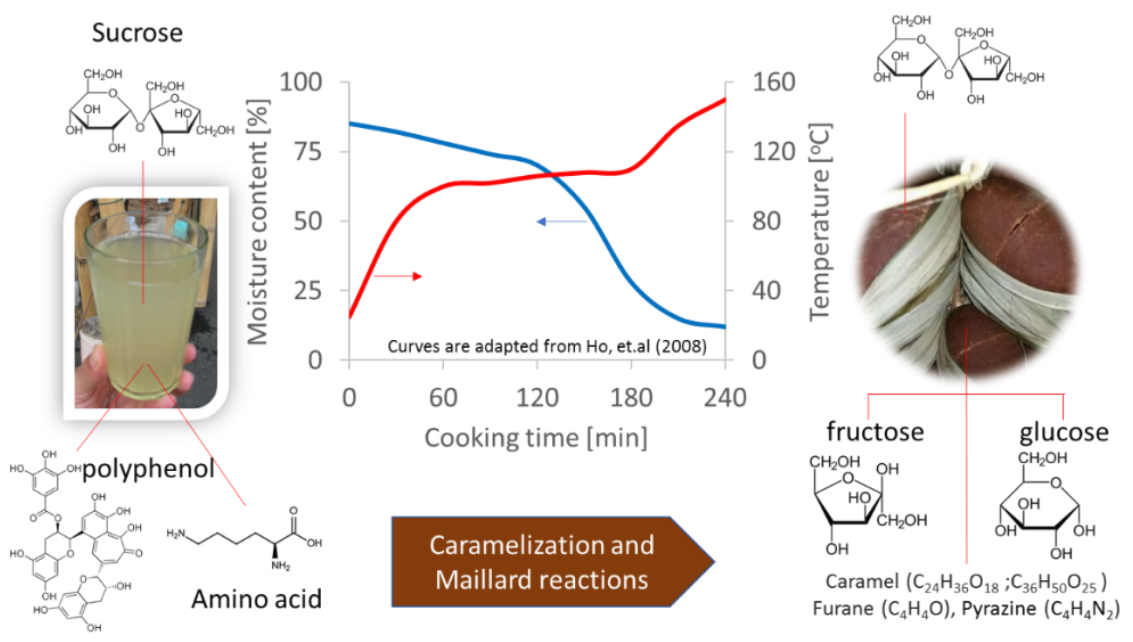

Figure 6. High temperature and a long cooking time leads to sugar browning 
(a)

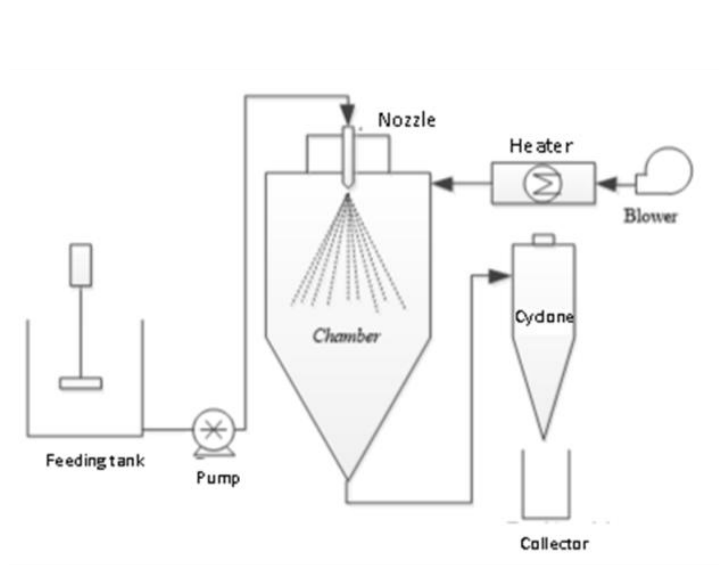

(b)

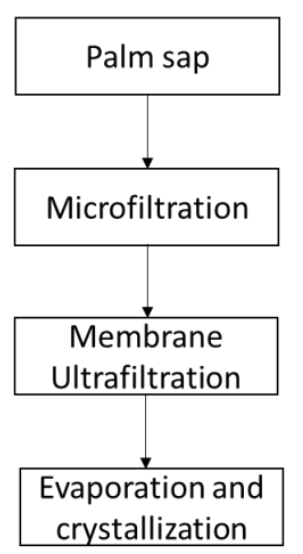

Figure 7. Applying technology on sugar processing (a) spray dryer (b) membrane ultrafiltration.

The weakness of producing sugar using spray drying is stickiness on the drying wall or changes to unwanted agglomeration in the drying chamber, and low product yield [39]. Sticky powder occurs due to cohesion-adhesion that can be explained in terms of adhesion between particles (cohesion) and particle-surface walls (adhesion). The forces which make powder particles stick to each other are called internal or cohesive properties that further form a powder lump. On the other hand, adhesion is an interfacial property that makes particle powder stick to the spray dryer wall surface. Both cohesion and adhesion force is a major parameter in designing a spray dryer that is responsible for the stickiness problem [39]. Factors that cause the stickiness of palm sugar production using a spray dryer are high hygroscopicity, thermoplasticity and low glass transition temperature $(\mathrm{Tg})$ of low molecular weight substances [39].

Several methods can be used to minimize stickiness problem, one of the way is to increase the glass transition temperature by adding materials that have high molecular weight and using cold air at the bottom of vessel [39]. Ingredients that have high molecular weight including maltodextrin, whey, casein, and soy protein. The function of proteins is to modify the surface of droplets and particles because proteins tend to migrate to water molecule interface within air from droplets which are atomized further and form protein films on drying that overcome the stickiness of sugar proteins. The film will convert a thick glass-like layer during the drying process. The study reported by Adhikari et al [40] found that addition of $0.5-1 \%$ sodium caseinate and whey protein to sucrose would minimize stickiness. Operating conditions of the spray dryer was $160 \mathrm{oC}$ for inlet temperature and $70 \mathrm{oC}$ outlet. The added protein composition could convert crystalline sucrose into an amorphous form. The presence of protein can improve powder recovery from $0 \%$ (pure sucrose) to $80 \%$ (protein addition). This happens because proteins are able to migrate to the air-droplet interface which driven by surface activity. Such thin layer occurs as protein-rich films quickly after contact with drying air. Thus, a film then changes to a glass condition and overcome the stickiness between each particles and particles with a wall that increased by temperature transition from the surface layer [40].
Spray drying is able to protect the sap component from unfavorable ambient conditions, minimize the loss of antioxidant content, total phenolic, amino acid content, and sugar content of palm sap [41]. Antioxidant content and the total phenolic content of palm juice using a spray dryer were $26.81-28.74 \%$ and $5.82-5.83 \mathrm{mg} / 100 \mathrm{~g}$ respectively.

\section{Membrane Technology}

The sugar industry is one of the food industries that have the most energy-intensive processes. Therefore, membrane technology has been extensively investigated by scientists in the past decade to increase the process efficiency in sugar processing (Figure 7b). Membrane filtration technology has been maintained in the sugar industry because of the improved quality and pre-treatment efficiency to produce value-added products. The sugar industry research organization, commercial manufacturing and membrane supplier company also sugar milling company have been actively involved in developing pilot plant utilization of membrane filtration in the sugar industry $[42,43]$.

Several process areas in the sugar industry use membrane systems, such as treatments of juice after liming with ultrafiltration (UF), treatment of liquid thickness after evaporation with UF, treatment of molasses using Electrodialysis (ED) or UF, and utilization of raw materials with UF [42]. The raw material for juice contains impurities such as salt, acid, protein and pectin. Colloidal impurities and some organic acids and ferri- and magnesium hydroxide can be deposited by $\mathrm{CaO}$. Ultrafiltration membranes can be used before liming to remove compounds with high molecular weight content. Another function is that it can reduce the use of $\mathrm{CaO}$ [44].

Membrane technology that is widely used in the food industry is the ultrafiltration membrane. This type of membrane can be used to concentrate solution while also providing separation process such wise to retain natural juice constituents like sugar, vitamins, volatile aroma profiles, and improve microbiological quality of permeate [45]. The concern of using membranes is fouling. Fouling can affect the effectiveness of microfiltration and filtration. 
Several studies reported no fouling problems during classification of raw juice with a tangential rate of $4 \mathrm{~m} / \mathrm{s}$ and no pre-treatment needed to achieve the same level achieved by conventional processes [46]. The use of ultrafiltration membranes can also affect raw materials to products in order to reduce sugar levels in sap and saps permeate syrups. The content of sucrose decreases and also causes loss of the pectin content of permeate. From the energy analysis the use of ultrafiltration membranes significantly decreases the heating and cooling area [45].

Heating process is one of the key comparisons between ultrafiltration and conventional method. Research conducted by Makhlouf-Gafsi, et al [47] regarding the comparison between thermal processes with ultrafiltration were analyzed on several parameters, including: for sugar and protein content, both thermal and ultrafiltration processes decreased. The total phenolic content for the thermal process was higher than that of ultrafiltration (354.3 vs. $328.36 \mathrm{mg}$ GAE / $\mathrm{mL}$ of total polyphenols) whereas the antioxidant activity of thermal process was lower compared to ultrafiltration $(3.76 \pm 0.07$ vs $4.93 \pm 0.08(\operatorname{IC} 50(\mathrm{mg} / \mathrm{mL})))$. The antimicrobial ratio between thermal processes with ultrafiltration depends on total phenolic content which means that antimicrobials with a thermal process are higher than the ultrafiltration process.

One type of ultrafiltration membrane that widely used in the food industry is ceramic membranes. Ceramic membrane is one of the most important inorganic membranes. The main types of ceramics used for the manufacture of filtration membranes are refractory oxides including: alumina, zirconia and titania. Nonetheless, a number of other ceramic materials such as cordierite, mullite, silicon nitride, silica and borosilicate glasses are suitable for the production of ceramic membranes. One of the advantages of using ceramic membranes is their endurance in order able to withstand hard operating conditions in terms of $\mathrm{pH}$, temperature, pressure and chemical stability. Ceramic membranes can be produced with different geometries such example: flat, tubular, multichannel or monolithic geometries. Ceramic membranes have been used successfully for the food industry [48]. The membrane material used for the sugar industry is material that is resistant to temperatures between $70-90^{\circ} \mathrm{C}$. Polymer membrane was not possible to reach high temperature levels. Therefore, the right material for this process is the ceramic membrane that has good resistance to high temperatures as well as flow rates and high pressure [49].

\section{Future Directions}

Palm sugar has huge potency to supply sugar demand of Indonesia while also reducing dependency of imported sugar. Arenga palm, coconut, and doub palm have already been exploiting for its sap and many other products. Indonesia is the largest palm oil producer in the world with 12.3 million hectares palm oil plantation with production 17 ton of fresh fruit bunches per hectares [50]. Palm oil sap that familiarly as neera is potential to exploit as one of raw materials for sugar production which have not exploited yet up to now.
Introduction advanced technology for sap tapping is critical to preserve sucrose from spoilage and deterioration Like using sterilization technique, put some ice to provide low temperature during tap sapping, are simple technique yet could improve the quality of palm sap [14]. Membrane has offered an attractive technique to reduce water content with lower energy supply than the evaporator technique. The membrane technology could improve the energy efficiency in sugar industry.

\section{Conclusions}

Various sugar palm in Indonesia are potential for alternative sugar resource instead of the sugarcane. For particular ecology perspective, many benefits could be taken by planting sugar palm. The sugar made of palm sap through traditional method contain more antioxidant which is healthier than the commercial white sugar made of sugarcane in factory. Palm sap tapping method is critical aspect for determining the quality of sugar because the sap is very sensitive and easy to deteriorate into other substances. Introducing advanced technology on sugar processing to improve sugar quality could be achieved by using spray dryer and membrane technology. New products could also be developed by these advanced technologies such as white healthy sugar and liquid colorless sugar in which could make farmer in village improve their prosperity.

\section{Acknowledgements}

The authors acknowledge the funding provided by IDB-UNTIRTA under project no.593/UN43.9/PL/2018.

\section{References}

[1] Wright, T.; Meylinah, S., Indonesia Sugar Annual Report 2017. Available: USDA Foreign Agricultural Service 2017.

[2] Sari, D.; Wegener, M., Indonesian Sugar Production and Recommendations for Industry Recovery. Available: SSRN 2015.

[3] Mogea, J.; Seibert, B.; Smits, W., "Multipurpose palms: the sugar palm (Arenga pinnata (Wurmb) Merr.)," Agroforestry Systems 13 (2), 111-129, 1991.

[4] Knight, G. R., "The sugar industry of colonial Java and its global trajectory," South East Asia Research 8 (3), 213-238, 2000.

[5] Martini, E.; Roshetko, J. M.; van Noordwijk, M.; Rahmanulloh, A.; Mulyoutami, E.; Joshi, L.; Budidarsono, S., "Sugar palm (Arenga pinnata (Wurmb) Merr.) for livelihoods and biodiversity conservation in the orangutan habitat of Batang Toru, North Sumatra, Indonesia: mixed prospects for domestication," Agroforestry Systems 86 (3), 401-417, 2012.

[6] BPS Data Sensus Pertanian; Statistics Indonesia: 2013 [Online]. Available: https://st2013.bps.go.id/dev2/index.php.[Accesed Jan. 15, 2018]

[7] Sutthachaidee, W., "Community Product Designed: A Case of Coconut Sugar Coffee Spoon," Procedia Economics and Finance 26, 1168-1172, 2015.

[8] Reshma, M. V.; Jacob, J.; Syamnath, V. L.; Habeeba, V. P.; Dileep Kumar, B. S.; Lankalapalli, R. S., "First report on isolation of 2,3,4-trihydroxy-5-methylacetophenone from palmyra palm (Borassus flabellifer Linn.) syrup, its antioxidant and antimicrobial properties," Food Chemistry 228, 491-496, 2017

[9] Tamunaidu, P.; Matsui, N.; Okimori, Y.; Saka, S., "Nipa (Nypa fruticans) sap as a potential feedstock for ethanol production." Biomass and Bioenergy 52, 96-102, 2013. 
[10] Subiandono, E.; Heriyanto, N. M.; Karlina, E., Potensi Nipah (Nypa fruticans (Thunb.) Wurmb.) sebagai Sumber Pangan dari Hutan Mangrove July 2016 [Online]. Available: http: //ejurnal.litbang.pertanian.go.id/index.php/bpn/article/view/5152/. [Accessed Jan. 30, 2017].

[11] Yamada, H.; Tanaka, R.; Sulaiman, O.; Hashim, R.; Hamid, Z. A. A.; Yahya, M. K. A.; Kosugi, A.; Arai, T.; Murata, Y.; Nirasawa, S.; Yamamoto, K.; Ohara, S.; Mohd Yusof, M. N.; Ibrahim, W. A.; Mori, Y., "Old oil palm trunk: A promising source of sugars for bioethanol production," Biomass and Bioenergy, 34 (11), 1608-1613, 2010.

[12] Lasekan, O.; Abbas, K. A., "Flavour chemistry of palm toddy and palm juice: a review," Trends in Food Science \& Technology, 21 (10), 494-501, 2010.

[13] M.Si., A., Drs. Suryanto; Nurbaya, S., "Pemeriksaan Kadar Alkohol Dalam Minuman Tuak". Jurnal Farmanesia, 3 (1), 22-23, 2016.

[14] Hebbar, K. B.; Pandiselvam, R.; Manikantan, M. R.; Arivalagan, M.; Beegum, S.; Chowdappa, P., "Palm Sap-Quality Profiles, Fermentation Chemistry, and Preservation Methods," Sugar Tech 2018.

[15] Victor, I. R. M. Processing Of Arenga Pinnata (Palm) Sugar. McGill University, Canada, 2015.

[16] Atputharajah, J. D.; Widanapathirana, S.; Samarajeewa, U., "Microbiology and biochemistry of natural fermentation of coconut palm sap," Food Microbiology 3 (4), 273-280, 1986.

[17] Hemstock, S. L., "The potential of coconut toddy for use as a feedstock for bioethanol production in Tuvalu," Biomass and Bioenergy 49, 323-332, 2013

[18] Naknean, P.; Meenune, M., "Impact of Clarification of Palm Sap and Processing Method on the Quality of Palm Sugar Syrup (Borassus Flabellifer Linn.)," Sugar Tech 17 (2), 195-203, 2015.

[19] Imawan Wahyu, H., "Economic Valuation of Nipa Palm (Nypa fruticans Wurmb.) Sap as Bioethanol Material," IOP Conference Series: Earth and Environmental Science 166 (1), 012045, 2018

[20] Eze, M. O.; Ogan, A. U., "Sugars of the unfermented sap and the wine from the oil palm,Elaeis guinensis, tree," Plant Foods for Human Nutrition 38 (2), 121-126, 1988.

[21] Heyne, K., Tumbuhan Berguna Indonesia. Yayasan Sarana Wana Jaya.: Jakarta, 1987; Vol. 1.

[22] Dalibard, C., Overall view on the tradition of tapping palm trees and prospects for animal production. Livestock Research for Rural Development 1999, 11 (5).

[23] Heryani, H.; Nugroho, A., "Study of Yellow Root (Arcangelisia Flava Merr) as a Natural Food Additive with Antimicrobial and Acidity-stabilizing Effects in the Production Process of Palm Sugar," Procedia Environmental Sciences 23, 346-350, 2015.

[24] Victor, I.; Orsat, V., "Characterization of Arenga pinnata (Palm) Sugar," Sugar Tech 20 (1), 105-109, 2018.

[25] Purnomo, H., "Sugar components of coconut sugar in Indonesia." ASEAN Food Journal 7 (4), 200-201, 1992.

[26] Misra, B., Neera: "The coconut sap: A review." International Journal of Food Science and Nutrition Volume 1, (4), 35-38, 2016.

[27] Naknean, P.; Meenune, M.; Roudaut, G., "Characterization of palm sap harvested in Songkhla province, Southern Thailand." International Food Research Journal 17, 977-986, 2010.

[28] Päivöke, A. E. A., "Tapping practices and SAP yields of the NIPA palm (NIPA Fruticans) in Papua New Guinea." Agriculture, Ecosystems \& Environment 13 (1), 59-72, 1985.

[29] Radam, R. R.; Sari, H. N. M.; Lusyani, H. L., "Chemical Compounds Of Granulated Palm Sugar Made From Sap Of Nipa Palm (Nypa Fruticans Wurmb) Growing In Three Different Places." Research Journal of Chemical Sciences Vol. 5(1), 18-26, January 2015.

[30] Zahari, M. A. K. M.; Zakaria, M. R.; Ariffin, H.; Mokhtar, M. N.; Salihon, J.; Shirai, Y.; Hassan, M. A., "Renewable sugars from oil palm frond juice as an alternative novel fermentation feedstock for value-added products." Bioresource Technology 110, 566-571, 2012.

[31] Shahirah, M. N. N.; Gimbun, J.; Pang, S. F.; Zakria, R. M.; Cheng, C. K.; Chua, G. K.; Asras, M. F. F., "Influence of nutrient addition on the bioethanol yield from oil palm trunk sap fermented by Saccharomyces cerevisiae." Journal of Industrial and Engineering Chemistry 23, 213-217, 2015.
[32] Murata, Y.; Tanaka, R.; Fujimoto, K.; Kosugi, A.; Arai, T.; Togawa, E.; Takano, T.; Ibrahim, W. A.; Elham, P.; Sulaiman, O.; Hashim, R.; Mori, Y., "Development of sap compressing systems from oil palm trunk." Biomass and Bioenergy 51, 8-16, 2013.

[33] Santiago-Urbina, J. A.; Verdugo-Valdez, A. G.; Ruiz-Terán, F., "Physicochemical and microbiological changes during tapping of palm sap to produce an alcoholic beverage called "taberna", which is produced in the south east of Mexico." Food Control 33, (1), $58-62,2013$.

[34] Ho, C. W.; Aida, W. M. W.; Maskat, M. Y.; Osman, H., "Changes in volatile compounds of palm sap (Arenga pinnata) during the heating process for production of palm sugar." Food Chemistry $102(4), 1156-1162,2007$

[35] Apriyantono, A.; Aristyani, A.; Nurhayati; Lidya, Y.; Budiyanto, S.; Soekarto, S. T., "Rate of browning reaction during preparation of coconut and palm sugar." International Congress Series, 1245 , 275-278, 2002.

[36] Abbès, F.; Kchaou, W.; Blecker, C.; Ongena, M.; Lognay, G.; Attia, H.; Besbes, S., "Effect of processing conditions on phenolic compounds and antioxidant properties of date syrup." Industrial Crops and Products 44, 634-642, 2013.

[37] Lasekan, O., "Influence of Processing Conditions on the Physicochemical Properties and Shelf-Life of Spray-Dried Palm Sugar (Arenga pinnata) Powder.” Drying Technology 32, (4), 398-407, 2014.

[38] Khuenpet, K.; Charoenjarasrerk, N.; Jaijit, S.; Arayapoonpong, S.; Jittanit, W., "Investigation of suitable spray drying conditions for sugarcane juice powder production with an energy consumption study." Agriculture and Natural Resources 50 (2), 139-145, 2016.

[39] Muzaffar, K.; Nayik, G. A.; Kumar, P., "Stickiness Problem Associated with Spray Drying of Sugar and Acid Rich Foods: A Mini Review." Journal of Nutrition \& Food Sciences (S12: S12003), 2015.

[40] Adhikari, B.; Howes, T.; Bhandari, B. R.; Langrish, T. A. G., "Effect of addition of proteins on the production of amorphous sucrose powder through spray drying." Journal of Food Engineering 94 (2), 144-153, 2009.

[41] Badmus, A. A.; Yusof, Y. A.; Chin, N. L.; Aziz, N. A., "Antioxidant capacity and phenolics of spray dried Arrenga pinnata juice powder." In International Conference on Agricultural and Food Engineering, CAFEi2016, 100, August 23-25, 2016.

[42] Rafik, M.; Qabli, H.; Belhamidi, S.; Elhannouni, F.; Elkhedmaoui, A.; Elmidaoui, A., "Membrane separation in the sugar industry." $J$. Chem. Pharm. Res. 7, 653-658, 2015.

[43] Doherty, W. O. S.; Rackemann, D. W.; Steindl, R. J., "Fouling of tubular ceramic membranes during processing of cane sugar juice." Desalination and Water Treatment 16, (1-3), 45-56, 2010.

[44] Trägårdh, G.; Gekas, V., "Membrane technology in the sugar industry." Desalination 69, (1), 9-17, 1988.

[45] Makhlouf-Gafsi, I.; Baklouti, S.; Mokni, A.; Danthine, S.; Attia, H.; Blecker, C.; Besbes, S.; Masmoudi, M., Effect of ultrafiltration process on physico-chemical, rheological, microstructure and thermal properties of syrups from male and female date palm saps. Food Chemistry 203, 175-182, 2016.

[46] Hinkova, A.; Bubník, Z.; Kadlec, P., "Membrane filtration in the sugar industry." Chem Pap. 54, 375-382, 2000

[47] Makhlouf-Gafsi, I.; Krichen, F.; Mansour, R. B.; Mokni, A.; Sila, A.; Bougatef, A.; Blecker, C.; Attia, H.; Besbes, S., "Ultrafiltration and thermal processing effects on Maillard reaction products and biological properties of date palm sap syrups (Phoenix dactylifera L.)." Food Chemistry 256, 397-404, 2018.

[48] Mancinelli, D.; Hallé, C., "Nano-Filtration and Ultra-Filtration Ceramic Membranes for Food Processing: A Mini Review." J. Membr. Sci. Technol. 5, (2015)

[49] Šereš, Z.; Gyura, J.; Eszterle, M.; Djurić, M., "Separation of nonsucrose compounds from syrup as a part of the sugar-beet production process by ultrafiltration with ceramic membranes." European Food Research and Technology 223, (6), 829-835, 2006

[50] Varkkey, H.; Tyson, A.; Choiruzzad, S. A. B., "Palm oil intensification and expansion in Indonesia and Malaysia: Environmental and socio-political factors influencing policy." Forest Policy and Economics 92, 148-159, 2018. 